
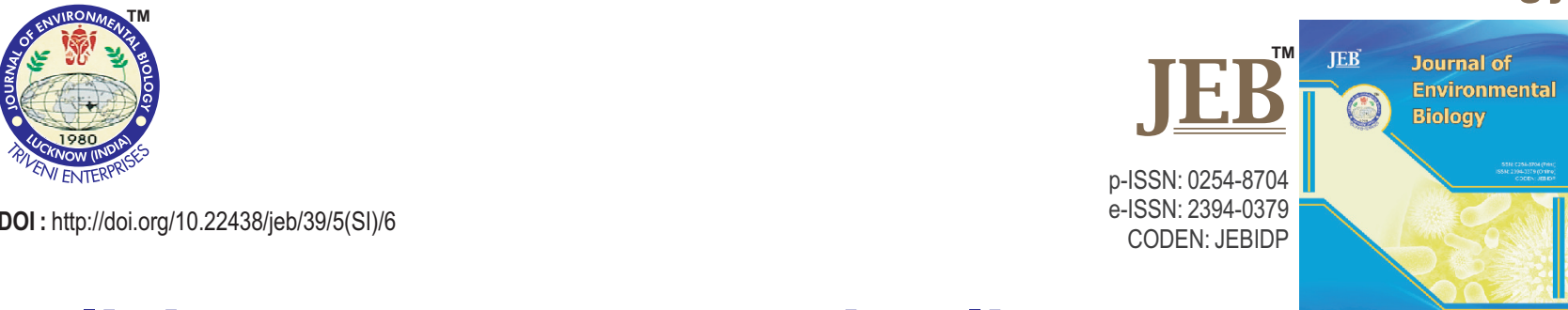

\title{
Salinity stress responses in Slipper cupped oyster Crassostrea iredalei from Setiu Wetlands, Terengganu, Malaysia
}

\section{Authors Info}

M. Nadirah ${ }^{1,2}$, W.W.I. Nurhafizah', A.S. Alia', N.A. Iberahim ${ }^{1}$, A.I. Zamani ${ }^{3}$, A.S.A. Soh ${ }^{1}$, A.A. Laith ${ }^{1,2}$, K.L. Lee ${ }^{1}$ and M. Najiah ${ }^{1,2 *}$

${ }^{1}$ School of Fisheries and Aquaculture Sciences, Universiti Malaysia Terengganu, 21030 Kuala Nerus, Terengganu, Malaysia

${ }^{2}$ Institute of Tropical Aquaculture, Universiti Malaysia Terengganu, 21030 Kuala Nerus, Terengganu, Malaysia

${ }^{3}$ Institute of Systems Biology, Universiti Kebangsaan Malaysia, 43600 UKM Bangi, Malaysia

${ }^{*}$ Corresponding Author Email : najiah@umt.edu.my

Key words

Aquaculture

Crassostrea iredalei

Functional responses

Haemocytes

Salinity stress

Publication Info

Paper received : 08.03.2017

Revised received : 07.6.2017

Re-revised received : 06.07.2017

Accepted : 28.12.2017

\begin{abstract}
Aim: The present study investigated some important functional responses to salinity stress in Slipper cupped oyster Crassostrea iredaleifrom Setiu Wetlands, Terengganu, Malaysia.
\end{abstract}

Methodology: Slipper cupped oysters were subjected to different salinities of 7, 14, 28 and 35 ppt for 2 weeks. Total haemocyte count (THC), phagocytic activity, ionic absorption, total protein concentration (TPC), superoxide dismutase activity (SOD) and histological changes of the oyster tissues were determined after 2 weeks of experiment.

Results: THC significantly decreased at $7 \mathrm{ppt}$ but increased at $35 \mathrm{ppt}(\mathrm{p}<0.05)$. The phagocytic activities were however not affected. The SOD activities were significantly higher $(p<0.05)$ at 7 and 14 ppt compared with 28 and 35 ppt. Higher TPC were also observed at 28 and 35 ppt. Potassium ion concentration (mmol $\mathrm{I}^{-1}$ ) increased gradually with the increasing salinities. Salinity stress was also associated with histological changes in the gills and digestive gland tubules of the oysters.

Interpretation: The present study has revealed the functional responses of $C$. iredalei to salinity changes, and the negative impact of low salinities on the oyster immune system.

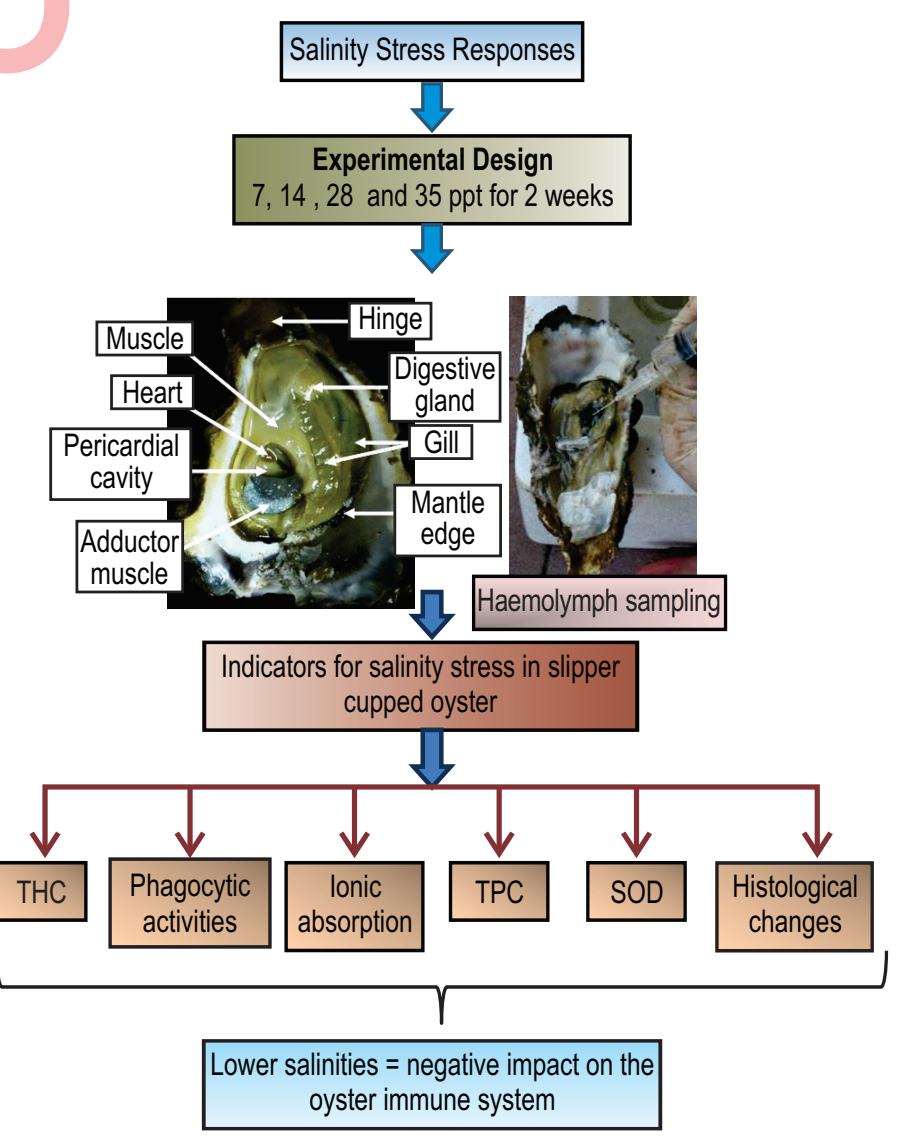




\section{Introduction}

Slipper cupped oyster, Crassostrea iredalei is one of the bivalve species in great market demand due to its sweetflavoured creamy flesh. This brackish water species is commercially important that provides good income to local communities in Malaysia. Most oyster farms in Malaysia operate in small scale in the intertidal areas that are vulnerable to salinity fluctuations (Devakie et al., 2008), due to tidal cycles, rainfall and drainage from adjacent terrestrial sites (Tirad et al., 1997). Although $C$. iredalei can survive a highly variable salinity regime, relatively limited data is available on their functional responses to salinity stress. Bivalve haemocytes play a crucial role in immune response, particularly the cellular defence via phagocytosis (Morga et al., 2010). This immune activity is, however, affected by abiotic factors of the aquatic environment (Cheng et al., 2004; Gagnaire et al., 2006), including salinity (Fuhrmann et al., 2016).

Oysters are sensitive to salinity changes and therefore salinity fluctuations may affect the survival of these sessile organisms. Setiu Wetlands of Terengganu at the Northeast of Peninsular Malaysia, is a unique inter-connected coastal ecosystem consisting of estuaries, lagoons, islands, mudflats, rivers, mangroves and coastal forests, that are separated from the South China Sea by a narrow stretch of barrier islands. Aquaculture is one of the major economic activities at Setiu Wetlands, including the culture of $C$. iredalei. Due to the interconnected nature of this ecosystem, the aquaculture water bodies are often exposed to high salinity fluctuations. This study was conducted to determine some important functional responses of salinity stress in C. iredalei from Setiu Wetlands with the purpose of providing some crucial baseline data for sustainable exploitation, conservation and future restoration of $C$. iredalei.

\section{Materials and Methods}

Experimental design : Crassostrea iredalei samples (95.2 \pm 8.5 $\mathrm{mm}$ ) were collected from Setiu Wetlands (Lat $5.66^{\circ} ; 5^{\circ} 39^{\prime} 36^{\prime \prime} \mathrm{N}$, Long $102^{\circ} 43^{\prime} 48^{\prime \prime} \mathrm{E} ; 102.73^{\circ}$ ). The oysters were acclimatized for 3 days at $28 \mathrm{ppt}$ (normal culture condition). After acclimatization, 10 oysters each with replicate were randomly allocated to 7,14 , 28 (control) and $35 \mathrm{ppt}$ salinities diluted from filtered full strength seawater in $30 \mathrm{I}$ glass tanks (water volume $15 \mathrm{l}$ ). The oysters were spaced approximately $6 \mathrm{~cm}$ apart (Sutton et al., 2012). A regular

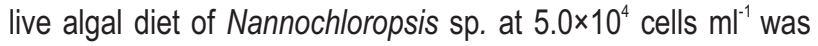
given daily. Tank water was changed $50 \%$ every alternate day. After 2 weeks, all the oysters were sampled. The oyster valves were slightly opened with a wedge, and the pallial cavity was rinsed thoroughly with physiological saline to remove the debris. Haemolymph was withdrawn from the adductor muscle using prechilled $23 \mathrm{G}$ needles with one $\mathrm{ml}$ syringe, and immediately discharged into a pre-chilled vial and kept in ice to avoid haemocyte clumping (Comesaña et al., 2012).
Total haemocyte count (THC) : Pooled haemolymph $(500 \mu$ l) was added to $19.5 \mathrm{ml}$ filtered seawater. Total haemocyte count (THC) was determined using hemocytometer and expressed as cells $\mathrm{ml}^{-1}$.

Phagocytosis : Five milligrams of dry yeast (AB Mauri, Malaysia) was suspended in $10 \mathrm{ml}$ solution 1:1 (filtered sea water, FSW and Congo red solution in 1:1 ratio). The suspension was autoclaved at $121^{\circ} \mathrm{C}$ for $15 \mathrm{~min}$, and washed twice with PBS by centrifugation at $1,300 \mathrm{~g}$ for $5 \mathrm{~min}$. The pellets were resuspended in $10 \mathrm{ml} \mathrm{FSW}$, and stored at $4^{\circ} \mathrm{C}$. The fixed haemocytes were washed five times with FSW, then overlaid with $100 \mu$ l of Congo red-stained yeast on slides, and incubated for $30 \mathrm{~min}$ at room temperature. Nonphagocytised yeast cells were removed by dipping the slides in filtered seawater for 10 times. The slides were then analysed under a compound microscope (Aladaileh et al., 2007).

Total protein concentration (TPC) : Total protein concentration was assayed according to Bradford, (1976) using bovine serum albumin (BSA) as standard. The absorbance of the sample was determined at $595 \mathrm{~nm}$, and compared with the control sample. The results were expressed as total protein concentration $\left(\mathrm{mg} \mathrm{ml}^{-1}\right)$.

Superoxide dismutase assay (SOD) : Superoxide dismutase assay was done calorimetrically at $450 \mathrm{~nm}$ using SOD determination kit (Sigma-Aldrich, USA). The specific activity of SOD was determined and expressed as unit $\mathrm{min}^{-1} \mathrm{mg}^{-1}$.

Ion regulation by inductively coupled plasma mass spectroscopy (ICP-MS) : Haemolymph samples were also subjected for estimation of potassium $\left(\mathrm{K}^{+}\right)$and calcium $\left(\mathrm{Ca}^{+}\right)$ions measurements using ICP-MS electrolyte analyser (Cheng et al., 2002).

Histology : Histological changes of the oyster tissues at different salinities were investigated by middle cross-section examination of each oyster. The soft tissues of oyster were fixed in $10 \%$ seawater-formalin, cross-sectioned at $4.5 \mu \mathrm{m}$, and stained with haematoxylin and eosin (Knowles et al., 2014) for microscopic viewing.

\section{Results and Discussion}

The internal defence of bivalve is implemented through a non-lymphoid immune system that is able to identify and eliminate potential pathogens very effectively. Anderson (1993) reviewed the modulation of immune function in bivalves by environmental stressors. The internal defence system of molluscs consists of both cellular and humoral immunities. The haemocytes, which are the most important cells involved in internal defence, circulate within an open vascular system across all epithelial boundaries and in extrapallial fluids (Paillard et al., 1996). The THC increased in parallel with water salinity (Fig. 1), was significantly highest $(p<0.05)$ at $35 \mathrm{ppt}$, and lowest at $7 \mathrm{ppt}$ 


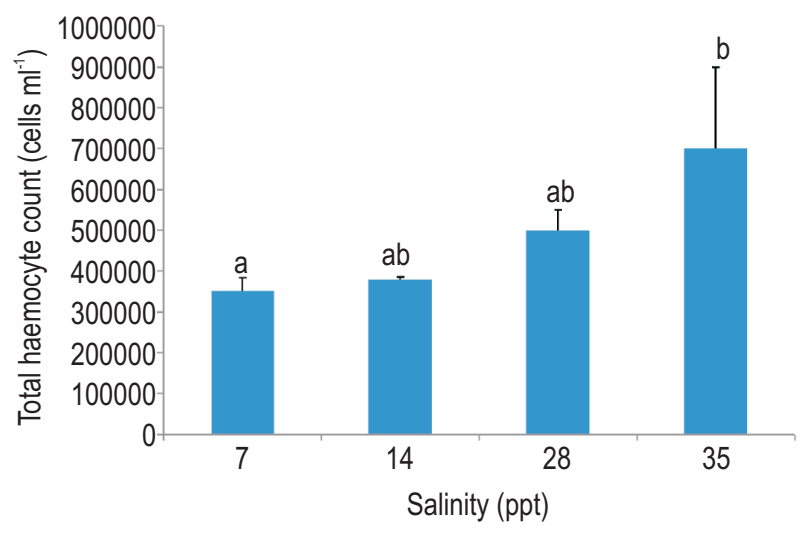

Fig. 1 : Total haemocyte count (THC) of Crassostrea iredalei at different salinities. Data was expressed as mean \pm standard deviation. Means with the same letters were not significantly different $(p>0.05)$

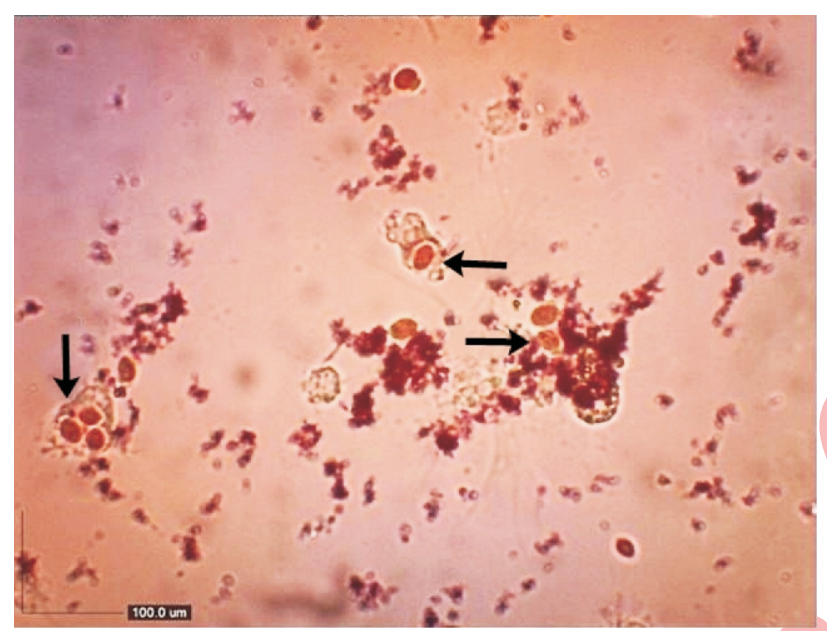

Fig. 3 : Yeast phagocytosis by Haemocytes of Crassostrea iredalei at 35 ppt (arrow)

compared with the control (28 ppt). A similar trend has been observed in other marine invertebrates, such as shrimp (Le Moullac and Haffner, 2000) and abalone (Cheng, Juang and Chen, 2004). Similar changes were also observed by Reid et al. (2003) in clam Ruditapes philippinarum, where THC increased with increase in salinity from 20 to 30 and 40 ppt. Further research is needed to clarify whether the increase in THC is the result of a higher haemopoiesis rate, or movement of cells from tissues into the circulation (Pipe and Coles, 1995). In addition, differential counts would certainly help determine the type of haemocytes that contribute to elevated THC. On the other hand, the decreased THC with the decreasing salinity could also be due to cell mortality (Gagnaire et al., 2006) or increased movement of the haemocytes from haemolymph to tissues.

Phagocytic activity (Fig. 2) was observed at all salinities, but was lowest at $7 \mathrm{ppt}$ (Fig. 3). Phagocytosis is a fundamental defence mechanism that multicellular animals have probably

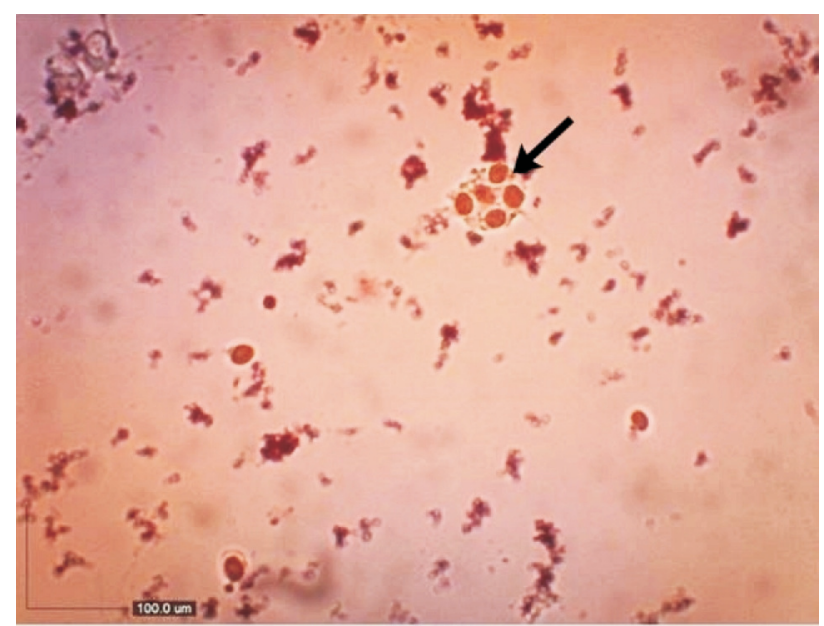

Fig. 2 : Yeast phagocytosis by haemocytes of Crassostrea iredalei at 7 ppt (arrow)

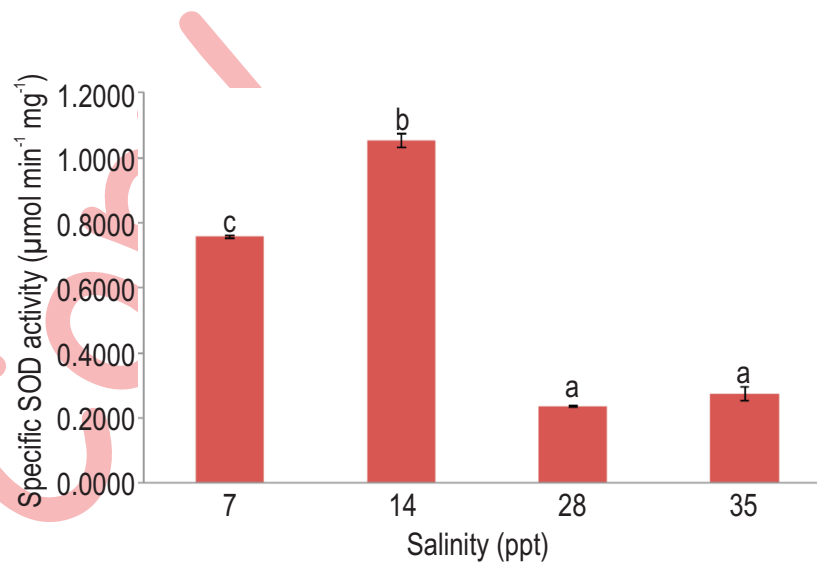

Fig. 4 : Specific SOD activities of Crassostrea iredalei at different salinities. Data was expressed as mean \pm standard deviation. Means with different letters were significantly different $(p<0.05)$

inherited from unicellular ancestors in which this played a role in food collection. Phagocytosis is the main cellular immune response against pathogens in molluscs (Feng, 1988; Cheng, 1981). It is a two-step process in which phagocytes must adhere to non-self particles before ingesting, and subsequently digesting them (Ballarin et al., 1994). Numerous studies have demonstrated that phagocytosis might be affected by the environmental changes (Oliver and Fisher, 1999). In our study, phagocytic activities were observed at 7, 14, 28 and 35 ppt, but were enhanced at higher salinities. As higher THC may correspond to higher number of phagocytes, lower salinity may therefore modulate the phagocytic activity of haemocytes towards the lower side, and compromise the defence mechanism. It is also possible that the immune system of oysters comprises with a range of interactive cell types and effector molecules that work together to maintain surveillance throughout the body of the organism (Fisher, 1986). The complexity and interdependence make the immunity in vertebrates and 


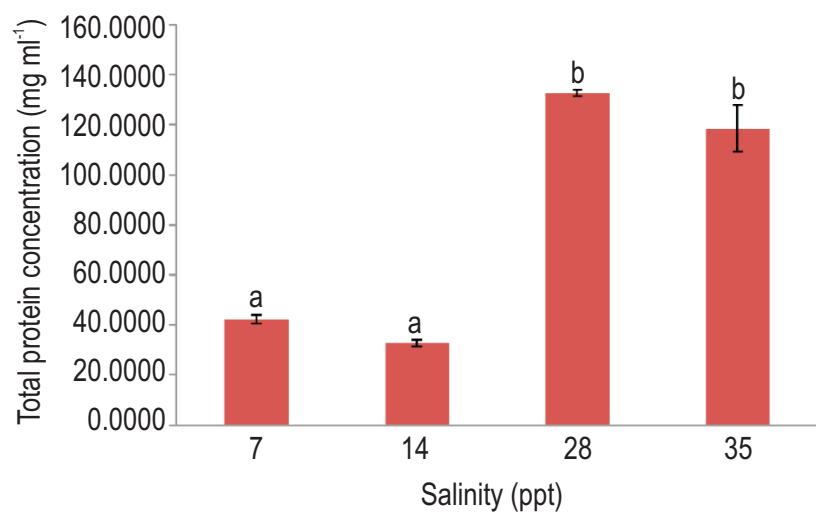

Fig. 5 : Total protein concentration (TPC) of Crassostrea iredalei at different salinities. Means with different letters were significantly different $(p<0.05)$

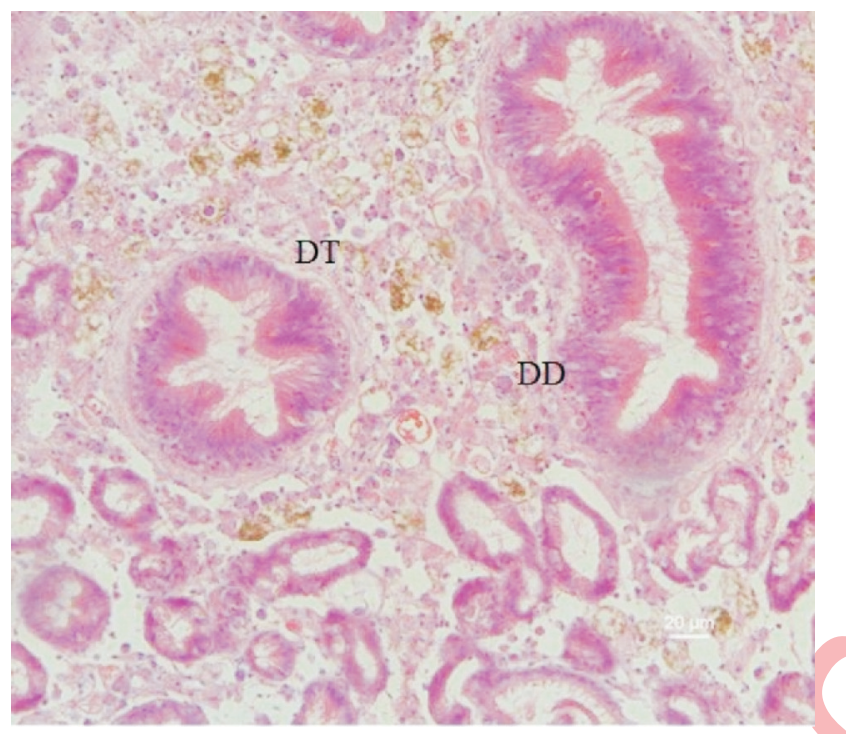

Fig. 7 : Normal digestive glands consist of digestive ducts (DD) and digestive tubules (DT) at $28 \mathrm{ppt}$ salinity

invertebrates particularly sensitive to environmental stressors, including exposure to contaminants (Mazumder et al., 2015). Detrimental alterations in the balance of the immune regulatory network may cause detectable and quantifiable changes in discreet components of the immune system (Paillard et al., 1996).

Enzymatic activities are associated with the ability of haemocytes to kill pathogens via phagocytosis. Haemocytes are known to contain hydrolytic enzymes that produce reactive oxygen species (ROS), which plays a major immunological role in many bivalve species (Gelder and Moore, 1986). Superoxide dismutase (SOD) is one of the ROS that is crucial to degrading pathogens, as well as exhibiting microbicidal activities (Labreuche et al., 2006). However, the release of ROS will be excessive under stress conditions. Over-activation of ROS production is believed to promote toxicity to the host cells, in

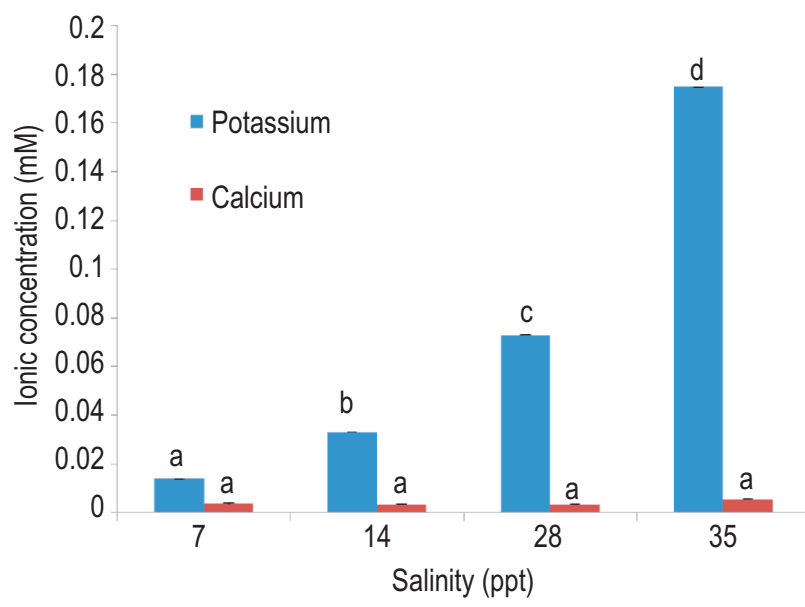

Fig. 6 : Potassium and calcium levels in haemolymph of Crassostrea iredalei at different salinities. Data was expressed as mean \pm standard deviation. Means with different letters were significantly different $(p<0.05)$

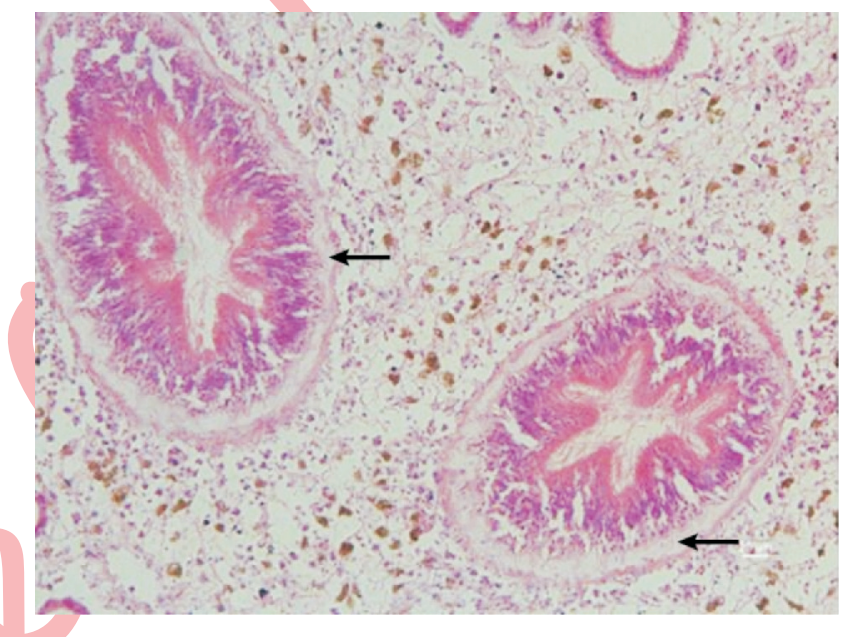

Fig. 8 : Expanded intercellular spaces of digestive tubules at 14 ppt salinity (arrow)

which haemocytes may be both the source and target of free radicals (Labreuche et al., 2006). Specific activity of SOD was measured, based on the inhibition of superoxide radical (xanthine oxidase). In the present study significantly elevated $(p<0.05)$ SOD activity was found at low salinities (7 and $14 \mathrm{ppt}$ ) compared with the control group, due to over production of SOD that possibly caused lipid peroxidation, tissue damage and weakening of the oysters. Gagnaire et al. (2006) reported high temperature and salinity incursions causing stress in Pacific oyster, leading to parasites or disease susceptibility.

Specific activities of SOD were significantly higher $(\mathrm{p}<0.05)$ at 7 and $14 \mathrm{ppt}$, but lowered at 28 and $35 \mathrm{ppt}$ (Fig. 4). A previous study by Terahara et al. (2005) reported apoptosis of haemocytes in Crassostrea gigas following exposure to ROS generated by the haemocytes themselves. The ROS produced 


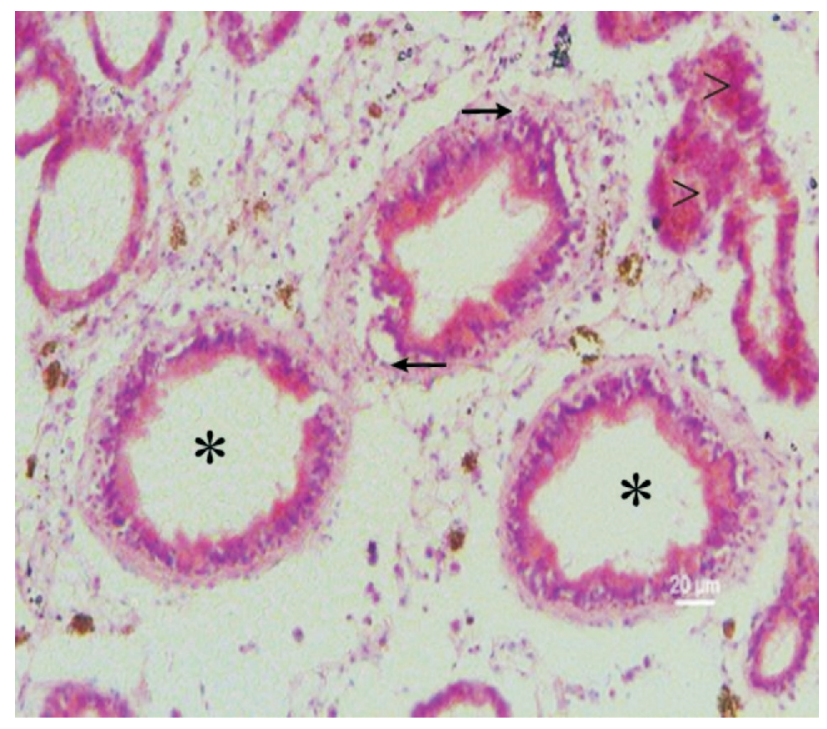

Fig. 9 : Haemocyte infiltration surrounding the digestive tubules and attached to the walls (arrow), necrosis (head arrow) and enlargement of tubules (star) at $7 \mathrm{ppt}$ salinity

during normal cellular metabolism are in balance with antioxidants under normal physiological conditions (Labreuche et al., 2006). Under stressful conditions, certain metalloenzymes are released to prevent excessive ROS production. Superoxide dismutase is known as the main endogenous antioxidant that protect tissues from oxidative damage, and defends against the overly-produced ROS.

The results showed that the TPC was highly reduced at low salinities (7 and $14 \mathrm{ppt}$ ) compared with $28 \mathrm{ppt}$. At $35 \mathrm{ppt}$, the TPC was slightly reduced than those of $28 \mathrm{ppt}$ (Fig. 5). In a previous study Campa-Córdova et al. (2002) demonstrated that exposure to immunostimulants might increase haemolymph TPC. Another study by Downs et al. (2001) reported that heat stress caused increased Mn-SOD, glutathione, heat shock proteins and ubiquitin in crustacean species, grass shrimp Penaeus pugio. The increase of TPC might be due to specific response of protein synthesis and denaturation (Ellis, 1996).

The potassium ion concentration ( $\mathrm{mmol} \mathrm{I}^{-1}$ ) gradually increased with increasing salinity from $7 \mathrm{ppt}$ to 14,28 and $35 \mathrm{ppt}$ (Fig. 6). The potassium ion concentrations at 7 and 14 ppt were significantly lower $(p<0.05)$ than those at $28 \mathrm{ppt}$, while this was significantly higher $(p<0.05)$ at $35 \mathrm{ppt}$ compared to $28 \mathrm{ppt}$. A similar trend in potassium was reported by Cheng et al. (2002) in the haemolymph of Taiwan abalone, Haliotis diversicolor supertexta. However, no significant differences $(p<0.05)$ were observed in the calcium ion concentration, suggesting that these were regulated to some degree (Fig. 6). However, Crassostrea iredalei has been reported to be an osmoconformer, in which the body fluid solute concentration conforms to or same as the solute concentration of the external medium in which the oyster lives.

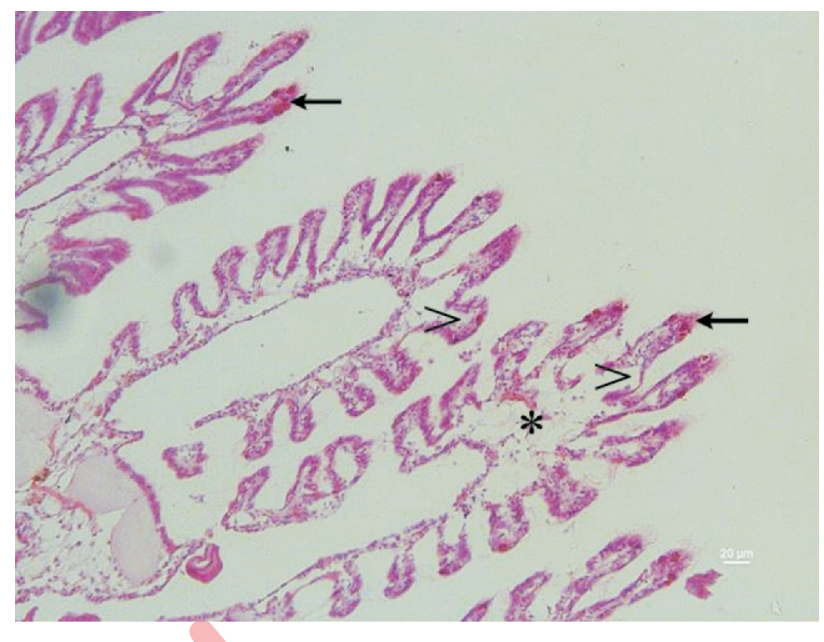

Fig. 10 : Enlargement of gill lamellae (head arrow), necrosis of gill lamellae (arrow) and ruptured gill structure (star) at $7 \mathrm{ppt}$

Changes in salinity may disrupt the osmotic balance of marine molluscs (Cheng et al., 2002). In osmoregulator organisms, the osmoregulatory ability, particularly during the early life stages of osmoregulator organism is assumed to be species-dependent (Nadirah etal., 2014).

Histological examinations showed changes in the gills and digestive gland tubules in intestine at lower salinities as compared to $28 \mathrm{ppt}$. At $7 \mathrm{ppt}$, haemocytes infiltrated into the walls of stomach, intestines and digestive gland tubules. In addition, many intracytoplasmic vacuoles were observed in the digestive glands (Fig. 7, 8, 9 and 10). Knowles et al. (2014) reported common histological changes in oysters at low salinities that included expanded intercellular spaces in the walls of the stomach, intestines and digestive glands with diffused haemocyte infiltrations in these organs, and expanded intercellular spaces in the kidneys. In the present study, at $7 \mathrm{ppt}$, the diffused haemocyte infiltration into the walls of the stomach, intestine and digestive gland tubules, as well as atrophy of digestive gland tubules were substantial. These changes were unlikely pathological, but homeostatic and immunological to offset the salinity stress, and thus prepare against possible pathogen invasion amid the stressful conditions.

Abiotic factors such as salinity is known to modulate hostpathogen interactions, and therefore affect the severity of diseases (Fuhrmann et al., 2016). In a previous study on C. iredalei from Setiu Wetlands, bacteria such as Shewanella putrefaciens, Vibrio parahaemolyticus, Vibrio vulnificus, Vibrio cholera, Enterobacter cloacae, Escherichia coli and Chromobacterium violaceum were found in non-diseased oysters under normal water conditions (Najiah et al., 2008), in which the oysters seemed to be immunologically capable of preventing opportunistic infections. These bacteria, however, may become pathogenic and induce infection if the oyster immune system is 
compromised. Such a compromise can be due to overwhelming stress, such as prolonged exposure to low salinity, during northeast monsoon affecting Setiu Wetlands from November to January, when the water body receives excessive freshwater from prolonged and heavy rainfall, as well as runoff from the surrounding areas.

In conclusion, the present study demonstrated some functional responses in Slipper cupped oyster, C. iredalei from Setiu Wetlands due to salinity stress. The THC, phagocytic activities and plasma potassium concentration were reduced in parallel with the decreasing salinities. The plasma calcium concentration, however, did not seem to be affected by the salinity changes suggested this was being regulated. The TPC was generally lowered at low salinities (7 and 14 ppt) compared with the normal 28 ppt salinity, while SOD activity was generally elevated at low salinities indicating a stress status in the oysters. The histological changes and haemocyte infiltration are possibly homeostatic and immunological responses to offset the salinity stress, and prepare against possible infections during the stressful condition. The findings of the present study can provide a better understanding of the impact of salinity fluctuation to sustainability of oyster culture at the Setiu Wetlands.

\section{Acknowledgment}

The authors thank the Ministry of Higher Education (MOHE) for providing the Fundamental Research Funding Scheme (FRGS/1/2012/ST03/UMT/02/3).

\section{References}

Aladaileh, S., S.V. Nair, D. Birch and D.A. Raftos: Sydney rock oyster (Saccostrea glomerata) hemocytes: Morphology and function. J. Invert. Pathol., 96, 48-63(2007).

Anderson, R.S.: Modulation of nonspecific immunity by environmental stressors(Eds.: J.A. Couch). Advances in Fisheries Science, Pathobiology of Marine and Estuarine Organism. p. 483-510 (1993).

Ballarin, L., F. Cima and A. Sabbadin: Phagocytosis in the colonial ascidian Botryllus schlosseri. Develop. Comp. Immunol., 18, 467-481 (1994).

Bradford, M. M.: A rapid and sensitive method for the quantitation of microgram quantities of protein utilizing the principle of protein-dye binding. Analyt.Biochem., 72, 248-254 (1976).

Campa-Córdova, A.I., N.Y. Hernández-Saavedra and F. Ascencio: Superoxide dismutase as modulator of immune function in American white shrimp (Litopenaeus vannamei). Comp. Biochem. Physiol., 133, 557-565 (2002).

Cheng, T.C.: Bivalves. In: N.A. Ratcliffe and A.F. Rowley, Editors, Invertebrate Blood Cells. Academic Press., London, p. 233-299 (1981).

Cheng, W., I. Hsiao, C. Hsu and J. Chen: Change in water temperature on the immuneresponse of Taiwan abalone Haliotis diversicolor supertexta and its susceptibility to Vibrio parahaemolyticus. Fish Shellfish Immunol., 17, 235-243 (2004).

Cheng, W., F.M. Juang and J.C. Chen: The immune response of Taiwan abalone Haliotis diversicolor supertexta and its susceptibility to Vibrio parahaemolyticus at different salinity levels. Fish Shellfish Immunol., 16, 295-306 (2004).

Cheng, W., S.P. Yeh, C.S. Wang and J.C. Chen: Osmotic and ionic changes in Taiwan abalone Haliotis diversicolor supertexta at different salinity levels. Aquaculture. 203, 349-357 (2002).

Comesaña, P., S.M. Casas, A. Cao, E. Abollo, I. Arzul, B. Morga and A. Villalba: Comparison of haemocytic parameters among flat oyster Ostrea edulis stocks with different susceptibility to bonamiosis and the Pacific oyster Crassostrea gigas. J. Invert. Pathol., 109, 274-286 (2012).

Devakie, M.N., M.T. MD-Saleh and A.R. Masazurah: Optimal cytochalasin B for induction of triploidy in tropical oyster, Crassostreairedalei(Faustino) embryos and their short-term survival rate. Malaysian Appl. Biol., 37, 57-62 (2008).

Downs, C.A., J.E. Fauth and C.M. Woodley: Assessing the health of grass shrimp (Palaeomonetes pugio) exposed to natural and anthropogenic stressors: Molecular biomarker system. Mar. Biotechnol., 3, 380-397 (2001).

Ellis, R.J.: Stress proteins as molecular chaperones. Stress Proteins in Medicine (Eds.: W. Van Eden and D.B. Young).Marcel Dekker Inc, New York (1996).

Feng, S.Y.: Cellular defense mechanisms of oysters and mussels. Ameri. Fish. Soc., 18, 153-168 (1988).

Fisher, S.W.: Structure and functions of oyster haemocytes. In: Immunity in Invertebrates (Eds.: M. Brehélin). Proceedings in Life Sciences. Springer, Berlin, pp. 25-35 (1986).

Fuhrmann, M., B. Petton, V. Quillien, N. Faury, B. Morga and F. Pernet: Salinity influences disease-induced mortality of the oyster Crassostrea gigas and infectivity of the ostreid herpesvirus 1 (OsHV-1). Aquacult. Environ. Int., 8, 543-552 (2016).

Gagnaire, B., H. Frouin, K. Moreau, H. Thomas-Guyon and T. Renault: Effects of temperature and salinity on haemocyte activities of the Pacific oyster, Crassostrea gigas (Thunberg). Fish Shellfish Immunol., 20, 536-547 (2006).

Gelder, S.R. and C.A. Moore: Cytochemical demonstration of several enzymes associated with phagosomal processing of foreign material within hemocytes of Mercenaria mercenaria. Trans. Ameri. Microscop. Soc., 105, 51 (1986).

Knowles, G., J. Handlinger, B. Jones and N. Moltschaniwskyj: Hemolymph chemistry and histopathological changes in Pacific oysters (Crassostrea gigas) in response to low salinity stress. $J$. Invert. Pathol., 121, 78-84 (2014)

Labreuche, Y., C. Lambert, P. Soudant, V. Boulo, A. Huvet and J. Nicolas: Cellular and molecular hemocyte responses of the Pacific oyster, Crassostreagigas, following bacterial infection with Vibrio aestuarianus strain 01/32. Microbes. Infec., 8, 2715-2724 (2006).

Mazumder, S.K., M. De, A.G. Mazlan, C.C. Zaidi, S.M. Rahim and K.D. Simon: Impact of global climate change on fish growth, digestion and physiological status: Developing a hypothesis for cause and effect relationships. J. Water Climate Change, 6, 200-226 (2015).

Morga, B., I. Arzul, N. Faury, A. Segarra, B. Chollet and T. Renault: Molecular responses of Ostrea edulis haemocytes to an in vitro infection with Bonamiaostreae. Develop. Comp. Immunol., 35, 323-333 (2010).

Le Moullac, G. and P. Haffner: Environmental factors affecting immune responses in Crustacea. Aquaculture, 191, 121-131 (2000).

Nadirah, M., A. Bolong, A. Munafi, K.K. Anuar, R. Yusof, R. Mohamad and M. Najiah: Suitability of water salinity for hatching and survival of 
newly hatched larvae of climbing perch, Anabas testudineus. Songklanakarin J. Sci. Technol., 36, 433-437 (2014).

Najiah, M., M. Nadirah, K.L. Lee, S.W. Lee, W. Wendy, H.H. Ruhil and F.A. Nurul: Bacteria flora and heavy metals in cultivated oysters Crassostrea iredalei of Setiu Wetland, East Coast Peninsular Malaysia. Vet. Res. Comm., 32, 377-381 (2008)

Oliver, L.M. and W.S. Fisher: Appraisal of prospective bivalve immunomarkers. Biomark., 4, 510-530 (1999).

Paillard, C., K.A. Ashton-Alcox and S.E. Ford: Changes in bacterial densities and hemocyte parameters in eastern oysters, Crassostrea virginica, affected by juvenile oyster disease. Aquatic Living Resour., 9, 145-158 (1996).

Pipe, R.K. and J.A. Coles: Environmental contaminants influencing immunefunction inmarine bivalve molluscs. Fish Shellfish
Immunol., 5, 581-595(1995).

Reid, H.I., P. Soudant, C. Lambert, C. Paillard and H. Birkbeck: Salinity effects on immune parameters of Ruditapes philippinarum challenged with Vibrio tapetis. Dis. Aquat. Org., 56, 249-258 (2003).

Sutton, A. E., K. Yankson and D.A. Wubah: The effect of salinity on particle filtrationrates of the West African mangrove oyster. $\mathrm{J}$. Young Investigators, 24, 55-59 (2012).

Terahara, K., K.G. Takahashi and K. Mori: Pacific oyster hemocytes undergo apoptosis following cell-adhesion mediated by integrinlike molecules. Comp. Biochem. Physiol., 141A, 215-222 (2005).

Tirard, C.T., R.M. Grossfeld, J.F. Levine and S. Kennedy-Stoskopf: Effect of osmotic shock on protein synthesis of oyster hemocytes in vitro. Comp. Biochem. Physiol., 116A, 43-49 (1997).
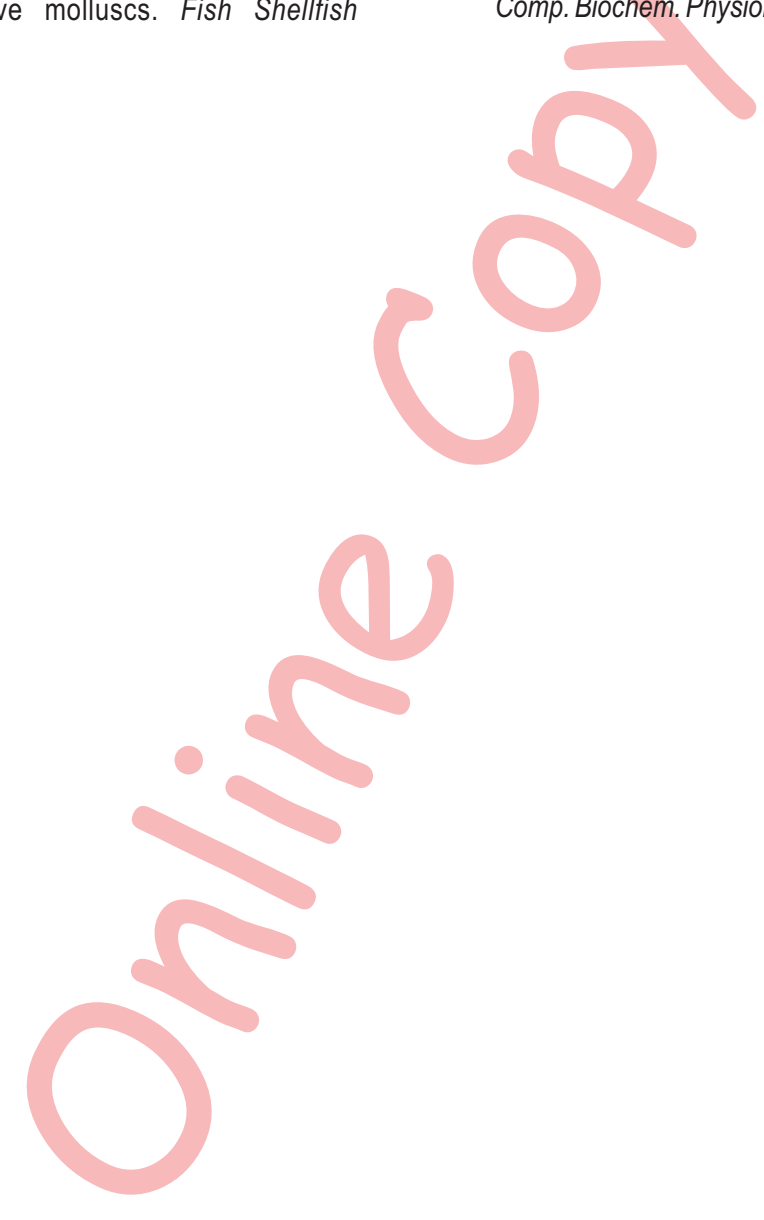